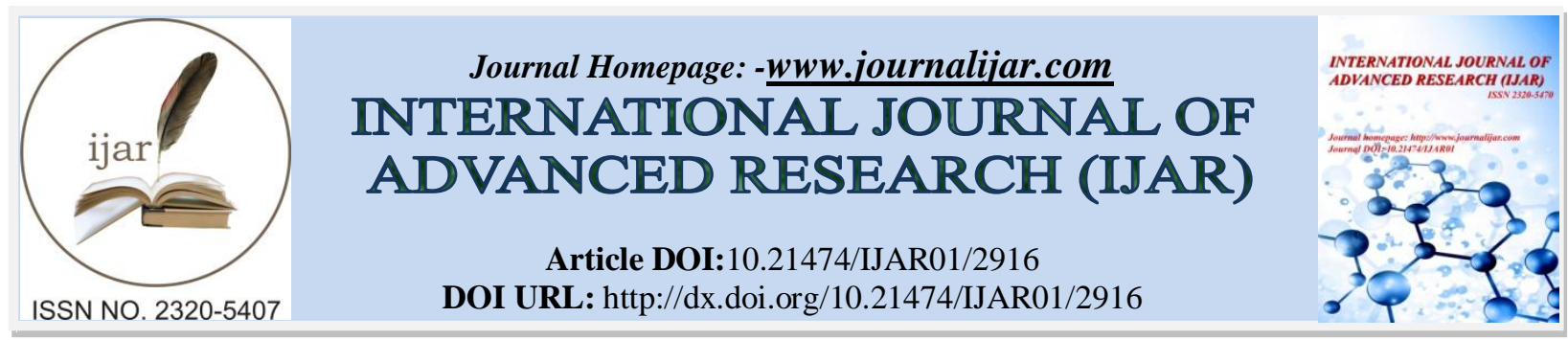

RESEARCH ARTICLE

\title{
SEVERE AND RECALCITRANT CHRONIC URTICARIA RESOLVED AFTER FILLER REMOVAL.
}

\author{
Abdulmajeed M Alajlan MD ${ }^{1}$, Amjad F Alshehri MD ${ }^{2}$ and Sami Al Suwaidan MD ${ }^{1}$. \\ 1. Associate professor, dermatology department, King Saud University. \\ 2. Medical intern, king Saud University.
}

\section{Manuscript Info}

Manuscript History

Received: 24 November 2016

Final Accepted: 25 December 2016

Published: January 2017

\section{Abstract}

Chronic idiopathicurticaria is a common skin disease without a clear etiology in the vast majority of cases. The main therapeutic options are directed towards histamine receptors. When antihistamines failed, other therapeutic options maybe added such as systemic steroids, mast cell stabilizer and more recently Omalizumab. Herein we report a rare case of severe and recalcitrant urticaria that was resistant to many treatments modalities including the above-mentioned drugs. Extensive patient history led to two possible triggers, which are lip fillers and tooth filling. Removal of bothfillings cured her disease completely.Dermatologists should be aware of any new procedures and materials administered to patients prior to development of urticaria.

Copy Right, IJAR, 2016,. All rights reserved.

\section{Introduction:-}

Urticaria for more than six weeks is considered chronic and in majority of cases more (80\%)no exogenous causes can bedetermined. The term chronic idiopathic urticaria (CIU) $[1,2,3]$ is commonly used. Antihistamines, systemic corticosteroids, mast cell stabilizers and biological therapy (omalizumab) are being used. Dermatologists often exposed to unresponsive cases to several treatment modalities. In this paper we are reporting a patient with severe and recalcitrant chronic urticaria for more than 7 months that is only completely resolved after removal of lip filler and tooth filling.

\section{Case Report:-}

46 years old female, medically free, presented to our clinic with history of severe urticarial for 7 months. The rash started to appear in the face with mild facial angioedema that progressed asgeneralized uriticaria all over the body. The patient started by herself on Cetirizine $10 \mathrm{mg}$ for two weeks, without benefit. Later on she was prescribed Hydroxyzine $25 \mathrm{mg}$ and loratidine $10 \mathrm{mg}$.Minimal response was noted and after two weeks she was started on Prednisolone $40 \mathrm{mg}$ in addition to the antihistamines.Up to $50 \%$ of the rash has improved over the body but angioedema over the face continued to appear. Montelukast $10 \mathrm{mg}$ and doubling the dosage antihistamines brought onlylittle benefit. Omalizumabinjection was initiated every week at $300 \mathrm{mg}$ that brought good benefit along with corticosteroid.Corticosteroid was tapered down till $10 \mathrm{mg}$ but patient stopped it completely because of weight gain. Urticaria flared up very significantly with Angioedema of the face (while she still on Omalizumab). Prednisolone 40 $\mathrm{mg}$ was taken by the patient irregularly for social occasions to suppress the hives. At this stage, she sought medical advice with other dermatologist. Detailed history revealed that patient has both tooth filling and lip filler(JUVEDERM VOLIFT, Allergan,inc.Irivne, California, USA) have been administered for her2 and 1 months 
prior to urticaria onset respectively. Patient was advised to remove lip filler first and in one month the tooth filling. Hyaluronidase was injected twice (three days apart) to dissolve the lip filler. However, within few days patient chose to remove the tooth filling by her dentist against our advice and not to wait for a month.In less than one week she noticed significant decrease in number of hives that completely disappeared in a month. She is off all treatments without any recurrence for more than six months.

\section{Discussion: -}

None of the theories of pathogenesis of chronic urticaria $(\mathrm{CU})$ has been fully established ${ }^{4}$. Thebest-developed hypotheses include the autoimmune theory, theories involving histamine-releasing factors, and the cellular defects theories 5 .IgEmediated, cell mediated and complement mediated were established as main pathogenesis 1 , Dermatologists commonly failed to find out exogenous causes only in 20 to $30 \%$ they could be determined. In the literatures, unusual triggers had been reported such as hidden infection including Helicobacter pylori ${ }^{6}$, Hepatitis A 7 and Hepatitis $\mathrm{C}^{8}$, eye drops and tooth filling have been reported. ${ }^{9,10}$. Local skin reaction to Hyaluronic acid at site of injectionis well known with all types of fillers that can be confusing as angioedema. In two reports, angioedema affecting lips post fillers has described, however in the first case ${ }^{11}$ it seems to be an overt reaction to local filler rather than a classic immune mediated angioedema. It occurs within minutes at the site of injection only and disappeared in few days. In the second one ${ }^{12}$ Herpes Simplex Virus has been associated with the swelling. In both papersfiller hasn't been dissolved and no recurrence has been reported. We expected in those patients that urticaria should continue to flare as long as fillers still in the body.

In contrast to our patient,generalized urticaria has happened within a three to four weeks of injectionand only cleared after dissolving lip filler and removal of tooth filling. Another case of urticarial vasculitis (approved by skin biopsy) has been reported ${ }^{13}$. Threeweeks after filler and resolved within six weeks later. However in this case filler hasn't been dissolved with hyaluronidase, which might doubt for the possible relationship to cause urticarial vasculitis. Another report of angioedema that related to hylauronidase rather than lip filler ${ }^{14}$ The possibility that the angioedema in this patient was related to the dissolved fillerrather than only hyaluronidasecannot be ruled out. The antigen exposure to the immune system following degradation byhyaluronidase is a possible pathogenesis.

In our patient, both lip filler and tooth filling were administered 1 and 2 months respectively prior to her symptoms. No clue to us which of them is the true culprit. Although we advised her to remove them one month apart, she decidedremoving themsimultaneously, which creates uncertainty, which is the main culprit. Complete remission of urticaria within few weeks of removal of booth fillings creates strong evidence for the cause-relationship. Nevertheless, the message from this patient is the importance of detailed and extensive history in finding the possible causes and relieving the frustration and safe huge cost.

\section{References:-}

1. Kaplan AP. Chronic urticaria: pathogenesis and treatment. J Allergy ClinImmunol 2004; 114:465.

2. Sheikh J. Autoantibodies to the high-affinity $\operatorname{IgE}$ receptor in chronic urticaria: how important are they? CurrOpin Allergy ClinImmunol 2005; 5:403.

3. Kulthanan K, Jiamton S, Thumpimukvatana N, Pinkaew S. Chronic idiopathic urticaria: prevalence and clinical course. J Dermatol 2007; 34:294.

4. Vonakis BM, Saini SS. New concepts in chronic urticaria. CurrOpinImmunol 2008; 20:709.

5. SarbjitSaini(2015). Chronic urticaria: Clinical manifestations, diagnosis, pathogenesis, and natural history. In Bruce S Bochner, Jeffrey Callen (Ed.),uptodate.

6. Liutu M, Kalimo K, Uksila J, Kalimo H. Etiologic aspects of chronic urticaria. Int J Dermatol 1998; 37:515.

7. Wedi B, Raap U, Kapp A. Chronic urticaria and infections. CurrOpin Allergy ClinImmunol 2004; 4:387

8. Daoud MS, Gibson LE, Daoud S, el-Azhary RA. Chronic hepatitis C and skin diseases: a review. Mayo ClinProc 1995; 70:559.

9. CarbonellA e. Urticaria-angioedema due to carboxymethylcellulose eye drops. - PubMed - NCBI. Ncbinlmnihgov. 2016. Available at: https://www.ncbi.nlm.nih.gov/pubmed/22812199. Accessed November 28, 2016.

10. Kal B, Evcin O, Dundar N, Tezel H, Unal I. An unusual case of immediate hypersensitivity reaction associated with an amalgam restoration. BDJ. 2008;205(10):547-550. doi:10.1038/sj.bdj.2008.981. 
11. Leonhardt J, Lawrence N, Narins R. Angioedema Acute Hypersensitivity Reaction to Injectable Hyaluronic Acid. Dermatologic Surgery. 2006;31(5):577-579. doi:10.1111/j.1524-4725.2005.31166.

12. Dougherty A, Rashid R, Bangert C. Angioedema-type swelling and herpes simplex virus reactivation following hyaluronic acid injection for lip augmentation. Journal of the American Academy of Dermatology. 2011;65(1):e21-e22. doi:10.1016/j.jaad.2010.11.043.

13. Alijotas-Reig J. Recurrent Urticarial Vasculitis Related to Nonanimal Hyaluronic Acid Skin Filler Injection. Dermatologic Surgery. 2009;35(Sup 1):395-398. doi:10.1111/j.1524-4725.2008.01049.x.

14. Andre PFléchet M. Angioedema after ovine hyaluronidase injection for treating hyaluronic acid overcorrection. Journal of Cosmetic Dermatology. 2008;7(2):136-138. doi:10.1111/j.1473-2165.2008.00377.x. 